\title{
The Role of Modern Medicine in Clarifying Definitions in Islamic Jurisprudence (Ta'rifaats fi al-Fiqh)
}

\section{INTRODUCTION}

In the usual circumstances, the medical professional is consulted by Islamic scholars when a problem related to medicine involving Muslim society arises; where a specific fatwa (Islamic ruling) is needed. Commonly, in this situation, there are possible implications on halaal (permissibility) and haraam (prohibitions) related to the medical conditions or issues. An example is the issue on the use of porcine -based, low molecular weight heparin (LMWH) for acute coronary syndrome. Islamic scholars would need to gather information from the medical fraternity with regards to the medical condition (acute coronary syndrome), the drug in question (low molecular weight heparin), other treatment modalities and their related outcomes. They would then formulate a ruling on whether the porcinebased therapy is permissible or prohibited for use in the medical condition by considering local situations using strict methods of Islamic Jurisprudence (qawa'id al-fiqh). The fatwa may change from time to time, depending on advances in medicine.

The contribution of modern medicine in understanding Islamic Law is more than situational. Modern medicine is seen to influence classical rulings in Islamic law related to everyday life. Advances in medicine may help to clarify, sometimes redefine classical concepts and terminologies in Islamic Jurisprudence (ta'rifaats $f i$ al-figh). This subsequently changes the interpretations of rulings in Islamic Law. These rulings involve Muslims' daily life, not just for specific medical conditions, illness or therapies. Some examples shall be illustrated in the subsequent paragraphs.

Figh, Shari'ah, Maqasid al-Shariah and the sources of Islamic Law

Fiqh (Islamic Jurisprudence) literally means 'understanding'. Figh, in Islam, technically encompasses the tenets of Islam (Aqidah), its ethics (Akhlaq), and Islamic Law (Shari'ah). To understand the term 'figh', one should consider the functional definition, where shari'ah is the law itself, while fiqh is the knowledge of that law (i.e its jurisprudence). ${ }^{1}$ Over the years, as specific disciplines in Islamic studies develop, fiqh according to some authors is restricted to the Islamic Law. Sometimes figh is used interchangeably with Shari'ah.

Al-Ghazali mooted the five purposes or higher objectives of the Islamic Law (Maqasid al-Shari'ah) which was agreed upon by most scholars. These objectives are to preserve:

(1) the religion;

(2) the life;

(3) the mind;

(4) the progeny and

(5) the wealth. ${ }^{1}$

In other words; any rule, regulations or law in Islam are meant to fulfil these objectives. Islamic scholars diligently take into account these objectives whenever they formulate a ruling (fatwa).

At individual level, Muslims subscribe to the Shari'ah as an act of obedience. At the community level, subscribing to the Shari'ah means securing societal safety and prosperity by achieving the higher objectives mentioned earlier.

In Islam, the Shari'ah Law is derived from three sources. They are the Holy Quran, Sunnah and Ijma'. Sunnah is defined as the tradition of the Prophet Muhammad (peace and blessing upon him - p.b.u.h.), while Ijma' is the consensus among the Companions of the Prophet. If the solution to a problem is not directly found from the three sources mentioned above, Islamic scholars will use similitude (Qias) of previous cases in deriving a ruling. The final source for deliberating a ruling is by ijtihaad. Linguistically, ijtihaad means 'to strive'. Technically, ijtihaad is where a qualified Islamic scholar or a group of scholars strive with all his/their capabilities to examine all available evidences from all sources of Islamic Law, while considering contemporary situations, to deduce a ruling. ${ }^{1}$

One should understand that rulings mentioned explicitly in the text of the Quran and Sunnah is 
definite (qat'ie). However, their implementation requires understanding of history, reasons for revelation of the text (asbaab al-nuzul and asbaab al-wurud) and context in order to achieve the actual objectives of that particular ruling. As society progresses in various aspects of life, issues which were never discussed during the time of the Prophet (p.b.u.h) arise. Islamic scholars often had to resort to Qias and Ijtihaad when dealing with these issues.

Islamic scholars often define important terminologies in fiqh by their linguistic meaning (ta'rif laghwi) and technical meaning (ta'rif shar'ie or istilaah) at the beginning of each lesson without fail. This methodology of expounding a subject matter can be observed in classical fiqh work such as Fathul Qarib Al-Mujib fi Syarhi Alfazh Al-Taqrib by Abu Abdillah Muhammad bin Qasim bin Muhammad Al-Ghazi, al-lqna' fi Hall Alfazh Abi Syuja' and Mughni al-Muhtaj ila Ma'rifah Ma'ani Alfaz al-Minhaj by Syamsuddin Muhammad bin Ahmad al-Khathib al-Syarbini, Tayseer al-'Allaam Sharh Umdatul-Ahkaam by Abdullah ibn AbdurRahmaan Aal Bassaam and many more. ${ }^{2-5}$ Obviously, this was to ensure that the discussions on the issues being considered are kept in the milieu of Islamic Law. In short, the definitions of concepts and terminologies in Islamic Jurisprudence (ta'rifaats $f i$ al-fiqh) determine the scope and interpretation of rules in the Sha'riah thereby directly influence the outcome of ljtihaad, which we are going to demonstrate later.

Modern medicine and the understanding of concepts and definitions in fiqh

In the subsequent paragraphs we shall look into three examples of classical concepts/terminologies in figh; and how modern medicine may help to clarify the interpretation and understanding of these concepts. Subsequently we are going to explore the possible implications to the outcome of ijtihaad, when modern medical knowledge is taken into account.

These examples are nafakha al-ruuh (ensoulment), rada' and bulugh. Again, we would like to reiterate that the clarification or redefinition of fiqh concepts/terminologies by modern medicine is only applied to issue which are not mentioned explicitly in the text of the Quran and Sunnah whereby definite rulings can be derived (qat'ie).

Example 1: Ensoulment and determination of when life begins based on the Sunnah of the Prophet (p.b.u.h.)

The day of ensoulment (nafakha al-ruuh) is defined as the day when the soul is blown into the human fetus. The Prophet (p.b.u.h) described the stages of human development in a tradition (hadith):

On the authority of Abdullah ibn Masood (radhi Allahu anhu - r.a.), who said:

The Messenger of Allah (p.b.u.h.), and he is the truthful, the believed, narrated to us, "Verily the creation of each one of you is brought together in his mother's womb for forty days in the form of a nutfah (a drop), then he becomes an alaqah (clot of blood) for a like period, then a mudghah (morsel of flesh) for a like period, then there is sent to him the angel who blows his soul into him and who is commanded with four matters: to write down his rizq (sustenance), his life span, his actions, and whether he will be happy or unhappy (i.e., whether or not he will enter Paradise). By the One, other than Whom there is no deity, verily one of you performs the actions of the people of Paradise until there is but an arm's length between him and it, and that which has been written overtakes him, and so he acts with the actions of the people of the Hellfire and thus enters it; and verily one of you performs the actions of the people of the Hellfire, until there is but an arm's length between him and it, and that which has been written overtakes him and so he acts with the actions of the people of Paradise and thus he enters it." [reported by Bukhari \& Muslim](in AnNawawi's Mataan Al-Arba'in)

Scholars differ in their opinion to the beginning of life based on the above narration. The Maliki and Hanbali schools of thought interpret that ensoulment occurs at day 40 of conception and this defines when life begins. The phrase "for $a$ like period (in the Arabic text - mithla zalika)" is interpreted as 'during the same period'. On the other hand, the Hanafi and the Shafie schools of thought interpret the phrase "for a like period" 
mentioned three times in the narration as cumulative; concluding that the day of ensoulment occurs at day 120 of conception. The understanding of the day of ensoulment influence the definition of abortion, handling of the aborted fetus and fiqh ruling related to the unfortunate mother.

The majority of Islamic scholars agree that fetus aborted after 120 days after conception (approximately 20 weeks period of gestation/ amenorrhea or 4 months of pregnancy) who have attained human form and showed evidence of life, i.e. crying at birth (istihlal) should be bathed, shrouded, prayed for and buried according to the Islamic rituals [Note that we calculate the days of conception to start approximately 2 weeks after the first day of last menstrual period (LMP) which is used to determine period of gestation/ amenorrhea]. This is based on the understanding that after 120 days where ensoulment takes place, the fetus is considered a complete human being. On the other hand, only shrouding and burying are required for fetus which is aborted before 120 days, whereby it do not have a human form and/or without exhibiting istihlal. ${ }^{6}$ In the former, the ruling in terms of prayers, fasting and other rituals for the mother is as if she had given birth (wiladah) while the latter, as if she is having menses.

With the availability of the ultrasound machine, the definition of attaining a human form can be confidently concluded. The fetus takes a human form as early as 42 days after conception in which prior to that, the embryo could not be differentiated from other animals. ${ }^{7}$ however, the fetal organ can only be identified as early as 80 days of conception (13 weeks of gestation/ amenorrhea), up to $97 \%$ of the time using a transvaginal ultrasound scan. ${ }^{8}$ In addition to the attainment of human morphology, fetal movements in the first trimester (i.e. up to the end of 12 weeks gestation/amenorrhea or approximately 70 days of conception) have been observed to be similar to those in the second and third trimester. ${ }^{9}$ This may be an indication that life has begun earlier in the first trimester (i.e. even before 120 days after conception). Based on evidences provided by modern medicine, it seems that the Maliki and Hanbali schools of thought which say that ensoulment occurred after 40 days is perhaps closer to the truth in the interpretation of the phrase "for a like period" mentioned in the hadith above.
Among the implications of clarifying the meaning of this hadith using modern medicine, is that, abortion after 40 days would require at least the ritual of bathing and shrouding if istihlal is not observed. ${ }^{6}$ In addition to that, Islamic scholars and medical practitioners should exercise caution in granting permissibility of therapeutic abortions 40 days after conception (approximately 8 weeks period of gestation/amenorrhea) as the fetus is considered a complete human being. Simply put, considering modern medical knowledge, the limit of 120 days has changed to 40 days, when it comes to deciding on the ruling of handling the aborted fetus, the mother and permissibility of therapeutic abortions.

Example 2: Rada' (breastfeeding) and the effect on nasab (progeny)

Rada' is defined as the act of breastfeeding. In the Islamic Law, the practice of wet-nursing fulfilling certain conditions will result in family ties/kinship between the child and the wet nurse. Family ties in the Shari'ah would directly affect the laws of marriage and aurah. In the modern days, the question arises when bottle-feeding is used to feed a child with breast-milk from another woman. Does this act results in family ties/kinship?

Derived from ijtihaad, The National Fatwa Council Malaysia rules that bottle-feeding does results in family ties. This opinion is also held by Dr Wahbah al -Zuhaili. ${ }^{10}$ However, Dr Yusuf al-Qaradhawi has a different opinion. He argued that kinship can only be as a result from the act of rada'(i.e. suckling/ breastfeeding). He quoted the Quran (an-Nisa 4:23) mentioning the importance of the word 'motherhood' with regards to rada' (suckling). ${ }^{11}$

Prohibited to you [for marriage] are your mothers, your daughters, your sisters, your father's sisters, your mother's sisters, your brother's daughters, your sister's daughters, your [milk] mothers who nursed you, your sisters through nursing, your wives' mothers, and your step-daughters under your guardianship [born] of your wives unto whom you have gone in. But if you have not gone in unto them, there is no sin upon you. And [also prohibited are] the wives of your sons who are from your [own] loins, and that you take [in marriage] two sisters simultaneously, except for what has already 
occurred. Indeed, Allah is ever Forgiving and Merciful [Quran (Surah an-Nisa' 4:23) Translation by Sahih International].

The Arabic text used 'for your [milk] mother who nursed you' is arda'nakum (from the root word rada').

The act of suckling where the child is close the woman's breast promotes motherly tenderness which cannot be acquired by bottle feeding. ${ }^{11}$ His ijtihaad elucidates that bottle feeding does not result in family ties/kinship.

Modern medicine has demonstrated that breastfeeding or the act of suckling stimulates the production of more oxytocin and prolactin in the mother. The oxytocin hormone has been proven to induce calmness and reduce stress; while both oxytocin and prolactin promotes affection and subsequently bonding between mother and child. ${ }^{12}$ In bottle-feeding, the hormonal benefits from suckling are apparently absent.

By considering the proofs from modern medicine, it may be concluded that the ijtihaad by Dr Yusuf al-Qaradhawi appear to be closer to the correct interpretation of the word rada' and what is wanted from the Quranic text. Thus, bottle-feeding of expressed breast milk do not results in family ties/ kinship.

Example 3: Determination of presumptive puberty

Bulugh [(puberty); baaligh - a person who has achieved puberty] is a stage where a person takes responsibility and accountability for their actions in Islam. The person who has achieved a state of baaligh is expected to perform the five obligatory pillars of Islam which are the shahaadah (testimony of faith), solah (formal prayers), saum (fasting during the month of Ramadan), zakat (obligatory alms) and Hajj (the pilgrimage to Mecca). ${ }^{13}$ In addition to that, they are also liable to punishment for wrong doings in the perspective of Islamic Law. ${ }^{1}$

Classically, bulugh is determined for boys when they had their first ejaculation and for girls when they had their first menses (menarche). ${ }^{14}$ This is based on the text from the Sunnah of the Prophet (p.b.u.h.) from two narrations of hadith below:
Ibn Abbas said: A lunatic woman passed by Ali ibn AbuTalib. He then mentioned the rest of the tradition to the same effect as Uthman mentioned. This version has: Do you not remember that the Messenger of Allah (p.b.u.h.) has said: "There are three whose actions are not recorded: a lunatic whose mind is deranged till he is restored to consciousness, a sleeper till he awakes, and a boy till he dreams (i.e. ejaculate or reaches puberty)" [reported by Abu Dawud];

And;

Narrated Aisha, Ummul Mu'minin: The Prophet (p.b.u.h.) said: "Allah does not accept the prayer of a woman who has menses (reached puberty) unless she wears a veil."

Abu Dawud said: This tradition has been narrated by Sa'id b. Abi 'Arubah from Qatadah on the authority of al-Hasan from the Prophet (p.b.u.h.)[reported by Abu Dawud]

In the two narrations, the Arabic words used for the indication of puberty is yahtalim (he dreams), i.e. ejaculates for boys; and haa-id (a menstruating person) for girls. Therefore, in the presence of these events (ejaculation and menstruation) the determination of puberty for a person is definite (qat'ie).

In the absence of the above mentioned signs, scholars would have to resort to ijtihaad to determine the age of presumptive puberty. This is because a sane person, for whatever medical condition or constitutional delay of puberty, could not be left irresponsible and unaccountable of his/ her actions as they aged and becomes psychologically mature.

In general, the Shafie and Hanbali scholars consider 15 years of age to be the presumptive age of puberty. While the Maliki and Hanafi schools of thought take 18 years as the limit to presumptive puberty. Their deduction of rulings are based on several occasions in history such as the prohibition by the Prophet for companions who are below 15 years of age to participate in the battle of Uhud (Reported by Ibn Hibban). The 18 year old limit was derived from Ibn Abbas opinion. ${ }^{14}$

The Maliki scholars, apart from taking menses as a 
definitive sign of puberty, also take the presence of pubic hair as a sign of baaligh. ${ }^{14}$ Earlier Islamic scholars, limited by technology available during their time, were not familiar to other physiological signs of puberty. Studies in modern medicine enable characterization of the signs of puberty in a more objective manner. Taking Maliki scholars' approach into consideration, contemporary Islamic scholars should also take other signs such as telarche (breast enlargement), gonarche (increase in testicular volume), increase height velocity, change in male voice and facial hair development as suggested by Tanner to determine presumptive puberty. ${ }^{15}$ Apart from classical Tanner staging of puberty, body composition has also been shown to be highly associated with the onset of puberty. ${ }^{16}$ In another study, the onset of puberty has been shown to be related to the pubertal timing of both parents. ${ }^{17}$ This gives a notion that, determining the age of presumptive puberty would require Islamic scholars to consider individualized age based on parental pubertal history. Both Islamic scholars and medical practitioner should also consider studying the population norm in determining the onset of puberty. The $97.5^{\text {th }}$ centile for age of the onset of puberty may be considered as the limit to presumptive puberty in specific populations.

In short, the advances of modern medicine with regards to puberty may warrant revisiting the methods used by Islamic scholars to determine the presumptive age of puberty (i.e. in the absence of definitive events - ejaculation and menstruation). The outcome of ijtihaad, after considering medical sciences in determining the limit of the presumptive age of puberty, may change how Muslims interpret accountability in their society. For example, in Islamic Law governing social order, the redefinition of the age of presumptive puberty is directly related to rules of inheritance and criminal judgment.

\section{Conclusions}

The role of modern medicine is more than a consult to formulate legal rulings/fatwa in solving medical related problems. The examples given illustrate how modern medicine help to clarify the concepts and definitions used in Islamic Jurisprudence (ta'rifaats fi al-fiqh). The clarification may influence the outcome of ijtihaad. Most importantly the article has elucidate that these issues are related with everyday rulings in Muslims lives such as managing burials for aborted fetus; and the rulings on prayers or fasting for women who just have had an abortion. The importance of collaboration, between medical experts and Islamic scholar in research for fatwa can never be more emphasized.

\section{REFERENCES}

1. Nyazee IAK. Theories of Islamic Law: The Methodology of Ijtihad. 1st ed. Pakistan: The International Institute of Islamic Thought; 1994.

2. Qasim bin Muhammad Al-Ghazi AAM bin. Fathul Qarib Al-Mujib Fi Syarhi Alfazh Al-Taqrib. Dar Ibn Hazim; 2005.

3. Abdur-Rahmaan Aal Bassaam A. Tayseer Al'Allaam Sharh Umdatul-Ahkaam. Darussalam; 2009.

4. Ahmad al-Khathib al-Syarbini SM. Al-Iqna' Fi Hall Alfazh Abi Syuja'. Dar Kitab al-'Alamiah; 2004.

5. Ahmad al-Khathib al-Syarbini SM. Mughni AlMuhtaj Ila Ma'rifah Ma'ani Alfaz Al-Minhaj. Dar Al Ma'arefah; 1997.

6. Muhammad Al-Bakri Z. Al-kafi \#366ם: adakah janin yang gugur perlu disolatkan? Pejabat Mufti Wilayah Persekutuan. http://muftiwp.gov.my/ en/artikel/al-kafi-li-al-fatawi/1335-al-kafi-366adakah-janin-yang-gugur-perlu-disolatkan. Published 2018. Accessed July 5, 2018.

7. Saadat S. Human embryology and the holy quran: an overview. Int J Health Sci (Qassim). 2009;3(1):103-109.

8. Ebrashy A, EL Kateb A, Momtaz M, et al. 13-14Week Fetal Anatomy Scan: a 5-Year Prospective Study. Ultrasound Obstet Gynecol. 2010;35 (3):292-296. doi:10.1002/uog.7444.

9. Van Dongen LG, Goudie EG. Fetal movement patterns in the first trimester of pregnancy. $\mathrm{Br} \mathrm{J}$ Obstet Gynaecol. 1980;87(3):191-193. http:// www.ncbi.nlm.nih.gov/pubmed/7387919.

10. SS Datuk Dr. Zulkifli Mohamad al-Bakri. Bayan Linnas Siri 70: Isu Berkenaan Ibu Susuan \&amp; Pelbagai Hukum (Kad atau Sijil Susuan). Pejabat Mufti Wilayah Persekutuan. http:// muftiwp.gov.my/ms/artikel/bayan-linnas/1138bayan-linnas-siri-70-isu-berkenaan-ibu-susuanpelbagai-hukum-kad-atau-sijil-susuan? highlight $=W z c w X Q==$. Published 2016.

11. Ghaly M. Milk banks through the lens of muslim scholars: One text in two contexts. Bioethics. 2012;26(3):117-127. doi:10.1111/j.14678519.2010.01844.x.

12. World Health Organization. Infant nutrition. In: 
Infant and Young Child Feeding: Model Chapter for Textbooks for Medical Students and Allied Health Professionals. ; 2009:1-99. doi:10.1111/ j.1740-8709.2009.00234.x.

13. Averroes. [Syarah Bidayatul Mujtahid Wa Nihayatul Muqtasid]. Vol 1. (Shiddiq A rasyad (Translator), ed.). Jakarta: Akbar Media

14. Muhammad Al-Bakri Z. Irsyad al-fatwa siri ke230: umur baligh menurut 4 mazhab dan had umur yatim. Pejabat Mufti Wilayah Persekutuan. http://muftiwp.gov.my/ms/ artikel/irsyad-fatwa/irsyad-fatwa-umum/2460irsyad-al-fatwa-siri-ke-230-umur-baligh-menurut -4-mazhab-dan-had-umur-yatim. Published 2018. Accessed July 5, 2018.

15. Emmanuel M, Bokor BR. Tanner Stages. StatPearls. 2017:7-10. http:// www.ncbi.nlm.nih.gov/pubmed/29262142.

16. Kirchengast $S$, Göstl A. Body composition characteristics during puberty in girls and boys from Eastern Austria. Int J Anthropol. 2006;21 (1):45-54. doi:10.1007/s11599-006-9004-3.

17. Wohlfahrt-Veje C, Mouritsen A, Hagen CP, et al. Pubertal onset in boys and girls is influenced by pubertal timing of both parents. J Clin Endocrinol Metab. 2016;101(7):2667-2674. doi:10.1210/jc.2016-1073.

\section{Mohammad Arif Shahar}

Department of Internal Medicine

Kulliyyah of Medicine

International Islamic University Malaysia (IIUM) 